\title{
Effect of 1-MCP Treatment on Keeping Quality of Tomato Fruits at Ambient Temperature
}

\author{
${ }^{1}$ Ahmed, M. E. M, M.M. Attia ${ }^{2}$, A.A. Al-Araby ${ }^{1}$, A.F. Abd El-khalek ${ }^{1}$ and M.A.F. El-Naggar ${ }^{1}$ \\ ${ }^{1}$ Horticulture Department, Faculty of Agriculture, Tanta University, Tanta, Egypt \\ ${ }^{2}$ Department of vegetable crops handling research, Horticulture research institute, Agriculture research center, Giza, \\ Egypt
}

Received: 6/9/2018

\begin{abstract}
The study was conducted during the spring 2017 and 2018 at the Horticulture Research Institute(A,R,C) in Giza, Egypt . Tomato fruits (Lycopersicum esculentum L.) obtained from a local field in Nawag village, Tanta city, Al-Gharbia Governorate, tomato were harvest at the Breaker-turning fruits stage, were chosen to the influence of 1methylcyclopropene (1-MCP) concentration on retarding ripening process of green tomato fruit and maintained quality, tomato fruit were fully immersed in aqueous $1-\mathrm{MCP}$ at 50,100 , and $150 \mu \mathrm{gL}^{-1}$ for $10 \mathrm{~min}$, then fruit quickly dried, and then kept in $20{ }^{\circ} \mathrm{C}$. Results indicated that $1-\mathrm{mcp}$ treatment were retained quality fruit firmness of tomatoes fruit in comparison to control especially high concentration.
\end{abstract}

Keywords: 1-MCP, Tomato, Fruit quality, Storage period.

\section{INTRODUCTION}

Tomato is one of the most popular produced and extensively consumed vegetable crops in the world (Grandillo et al., 1999). It can be eaten raw in salads or as an ingredient in many dishes, and in drinks (Alam et al., 2007). Tomatoes and tomato-based foods provide a wide variety of nutrients and many health-related benefits to the body.

Worldwide postharvest tomato losses are as 30 to $40 \%$ (Kader, 1992) and even much higher in some developing countries such as Egypt due to the use of improper handling procedures and lack of methods to prevent decay and senescence (Prigojin et al., 2005). Currently, fungicides are used to control pre-harvest losses of tomato production (Baider and Cohen, 2003), but the use of prophylactic chemicals in these commodities (tomato fruits) is not allowed in different countries due to oncogenic risks (Unnikrishnan and Nath, 2002).

The tomato crop is an important vegetable crop in Egypt. The average area planted with tomatoes is about 545 thousand feddans, (8.625 million tons), (FAOSTAT, 2014), which represents $34 \%$ of the total vegetable area in Egypt. Tomatoes are also considered export crops, which makes it one of the sources of foreign currency.

1-MCP prevents ethylene effects in a broad range of fruits, vegetables and floriculture crops. Effective concentrations are low and range from 2.5 $\mu \mathrm{l} / 1^{-1}$ to $1 \mu \mathrm{l} / \mathrm{I}^{-1}$. Concentration interacts with temperature such that low concentrations of $1-\mathrm{MCP}$ applied over longer durations may be as effective as high concentrations. 1-MCP is most commonly applied at $(20-25 \mathrm{C})$, but can be used at lower temperatures in some commodities.

Generally, treatment durations of (12-24 h) were sufficient to achieve a full response. A variety of factors may need to be considered when using 1-MCP including cultivar, developmental stage, time from harvest to treatment, and multiple applications. Depending on the species being treated,1-MCP may have a variety of effects on respiration, ethylene

Corresponding author e-mail: dr.memahmed @yahoo.com production, volatile production, chlorophyll degradation and other color changes, protein and membrane changes, softening, disorders and diseases, acidity and sugars.

The objective of the present study was to investigate the influence of aqueous 1-MCP at different concentrations, immersion duration, and solution longevity on delaying ripening and maintained quality of tomato fruit.

\section{MATERIALS AND METHODS}

\section{Plant material}

Tomato (Lycopersicum esculentum L.) cv. "086 F1", were obtained from a local field in Nawag village, Tanta city, Al-Gharbia governorate. After picked fruits were transferred to the postharvest laboratory in the institute of horticulture research $(A, R, C)$. Fruits were kept for 30 days at $20^{\circ} \mathrm{C}$, at which time the majority of fruit had reached breaker-turning stage. Fruit were selected for uniformity of developmental stage and size,

Fruits were packed in cartoon boxes and immediately transported to The Department of vegetable crops handling research, Horticulture research institute, Agriculture research center, Giza, Egypt.

Transportation period was nearly was $2-3$ hours at $20-25{ }^{\circ} \mathrm{C}$. In the laboratory, the fruits were divided into four treatments as the following:

1-The first treatment fruits were washed, air dried, immersed in distilled water for 10minutes, dried again, and kept for 30 day at $20{ }^{\circ} \mathrm{C}$ (control).

2-The second, the third and the fourth treatments fruits were washed, air dried, and immersion in aqueous solution of 1 -MCP $\left(50,100,150 \mu \mathrm{gL}^{-1}\right)$ respectively, for 10 minutes , dried again , and kept for 30 day at 20 $\circ \mathrm{C}$.

Fruit samples for each treatment were stored to determine the physical and chemical changes in tomato fruits at 30 days intervals during cold period .physical and chemical properties were determined including weight loss percentage, decayed fruits (pathological), fruit peel color, fruit firmness, total soluble solid (TSS), titratable acidity, expressed as anhydrous citric acid,

Volume 7 (2): 63-72 
total soluble solids/acid ratio and ascorbic acid content (vitamin c).

Each treatment comprised 6 carton boxes and every box containing 18 fruits divided into 3 replicates each of 6 fruits to determine the physical and chemical characteristics, each box of each consider treatment was used at each examined period.

\section{MCP treatments}

Three groups of 36 fruit each were treated with aqueous 1-MCP prepared from formulation which containing $0.14 \%$ of $1-\mathrm{MCP}$ as active ingredient was released from a commercial powdered formulation (Smart Fresh ${ }^{\mathrm{TM}}$ Rohm and Hass Inc., USA) by adding distilled water, according to the manufacturer's instructions.

Solutions were prepared with 1-MCP powder at 50,100 , and $150 \mu \mathrm{gL}^{-1}$ (active ingredient). Quantities of powder containing the desired levels of active ingredient were suspended in $10 \mathrm{~L}$ of distilled water in $20 \mathrm{~L}$ plastic buckets and swirled gently with a plastic spatula for $10 \mathrm{~min}$. The solutions were used no sooner than $10 \mathrm{~min}$ and no later than $45 \mathrm{~min}$ after preparation, and all immersion treatments were completed within $100-150 \mathrm{~min}$. The fruit were immersed (12 fruit per immersion cycle) into the solutions and covered with a weighted, plastic perforated plate to ensure complete coverage of the fruit during the immersion period. After removal, the fruits were quickly drained and wiped dry with a paper towel. The fruits were then placed on plastic trays and transferred to storage at $20{ }^{\circ} \mathrm{C}$. Half of the fruit (18) from each treatment were used for determination of whole-fruit firmness and surface hue. To investigate the effects of immersion duration, a 1MCP solution was prepared at a concentration of 50 $\mu 1 / 1^{-1}, 20{ }^{\circ} \mathrm{C}$. Twenty minutes after preparation, tomato fruit at breaker-turning stage were immersed (15 fruit per immersion duration) for $10 \mathrm{~min}$. Fruit not immersed in 1-MCP were used as controls. Fruit firmness and surface color were measured as described below. Longevity of 1-MCP solutions was tested using $10 \mathrm{~L}$ of aqueous 1 -MCP at $100 \mu 1 / 1^{-1}$ held in an open $20 \mathrm{~L}$ plastic container at $20{ }^{\circ} \mathrm{C}$.At intervals from 20 min through 24 $\mathrm{h}$ after preparation, fruit were immersed (15 fruit per immersion duration) in the $1-\mathrm{MCP}$ for $1 \mathrm{~min}$, dried, and surface color and firmness were monitored as described below.

\section{Methods of determining physical properties Fruit weight loss percentage:}

Fruits (of each replicate) to be assessed at the considered dates were weighted at the beginning of the experiment and that specified date. Fruit loss percentage was calculated by following equation: fruit weight loss percentage after storage $=$ \{initial fruit weight (at the beginning of storage) - fruit weight at the specified period / /initial fruit weight (at the beginning of storage) $\times 100$

Fruit firmness

Fruit firmness was determined using (penetrometer). Firmness was measured using a $0.05 \mathrm{~N}$ load cell and a $7.5 \mathrm{~mm}$ diameter stainless steel probe. After establishing zero-force contact between the probe and the fruit, fruit was compressed $2.5 \mathrm{~mm}$ at 2 equidistant points along the equatorial region of each fruit. The maximum force $(\mathrm{N})$ generated during probe travel was used for data analysis, and the peak of resistance was recorded in six fruits, two from each replicate on the two opposite of fruit sides, the fruit firmness was measured as newton .

\section{Fruit external color measurement}

Fruit surface color (hue angle) was determined on 20 individual fruit per treatment using a Minolta CR400 colorimeter (Minolta camera Co. Ltd., Japan) with a standard C illuminant.

For the estimation of ( $\mathrm{L}, \mathrm{C}$ and $\mathrm{H}$ ) values and to evaluate color values as hue angle, according to (Poyesh et al. (2017).

\section{Fruit decay}

Where the measurement of the proportion of diseases through the periodic examination every seven days and so was examined five times using the following assessment:

Decay score $(1=$ none, $2=$ slight, $3=$ moderate, $4=$ moderately severe and $5=$ severe)

\section{Fruit visual appearance}

Where it was measured with the quality of the external appearance of fruits by periodic inspection every seven days and so was examined five times using the following evaluation:

Visual quality score $(9=$ excellent, $7=\operatorname{good}, 5=$ fair, $3=$ poor, $1=$ un-useable).

\section{Chemical properties}

Fruit Total soluble solids (TSS): Total soluble solids percentage was determined and measured using a hand refractometer, 0-32 scale (ATAGO N-1 $\mathrm{E}$, Japan) and expressed in ${ }^{\circ}$ Brix after making the temperature correction at $20^{\circ} \mathrm{C}$ according to AOAC (2000).

Fruit Ascorbic acid content: Ascorbic acid was determined by using 2, 6- dichlorophenolindophenol and $2 \%$ oxalic acid as a substrate according to AOAC (2000) and calculated as $\mathrm{mg} / 100 \mathrm{ml}$ of the juice.

Titratable acidity percentage: Titratable acidity was determined as citric acid by titration against sodium hydroxide $(0.1 \mathrm{~N})$, using phenolphthalein as an indicator. Acidity was calculated as grams of malic acid per 100 $\mathrm{ml}$ of juice according to AOAC (2000).

\section{Statistical analysis}

The effects of 1-MCP treatments, shelf life periods and their interactions on different characteristics were analyzed statistically by analysis of variance (ANOVA) using the EXCEL software (2016) and means comparison by LSD at $0.05 \mathrm{p}$.

\section{RESULTS AND DISCUSSION}

\section{Mean performance}

A- Physical characteristics

\section{A.1- Fruit weight loss percentage}

The graphs in Figure 1 showed that weight loss percentages for fruit treated with 50 and $100 \mu \mathrm{gL}^{-1}$ were nearly mid-way between control fruit and those treated with $150 \mu \mathrm{gL}^{-1}$ from about 7 to 28 days and gave 14.06 , $9.02,7.85$ and $3.73 \%$ for control, 50, 100 and 150 
$\mu \mathrm{gL}^{-1}$ after 28 days of storage, respectively in season 2017. In addition, control fruit and fruit treated at all concentrations had similar weight loss percentages and slowly increased until 14 days of storage then the rate of loss percentage increased faster to maxima of 10.70 , $8.16,5.61$ and $5.36 \%$ with concentrations of control, 50,100 and $150 \mu \mathrm{gL}^{-1}$ of $1-\mathrm{MCP}$ treatments in season 2018, These results agree those of El - Sheikh (1998). This increase in weight loss might be attributed to respiration and other senescence related to metabolic processes during storage, The 1-MCP treatments might reduce respiration rate of the fruit and inhibited ripening processes which diminished the weight loss of fruit during storage (Watkins, 2002) and thereby extend the storage life of tomato fruits (Blankenship and Dole, 2003).

\section{A.2- Fruit firmness}

Tomato fruit firmness started from initial values around 8.87 and 8.95 newton in the first and second seasons, respectively without significant differences between the different 1-MCP concentrations in the zero-date storage period (Figure 2).

The tomato fruit firmness average values in Figure 2 were observed to be significantly decreased corresponding to the continues storage days and reached from 8.87 and 8.95 newton in the beginning of storage to 4.20 and 4.27 newton after 28 days in season 2017 and 2018, respectively. On the other hand, tomato fruits firmness values were observed to be increased with the increasing of 1-MCP concentrations and ranged between 5.74 and 5.75 newton after zero date to 7.50 and 6.60 newton after 28 days during the first and the second seasons, respectively. Similar results were reported by El-Sheikh et al. (1998). The decline in fruit firmness may be due to the gradually breakdown of proto-pectin to lower molecular weight fractions which are more soluble in water and this was directly correlated with the rate of softening of the fruit (Wills et al., 1981), All over the storage period, however, fruits treated with $1-\mathrm{MCP}$ at100and $150 \mu \mathrm{gL}^{-1}$ was the most effective treatment. These results were in agreement with those obtained by Celso et al .(2001), who found that tomato fruits treated with 1-MCP showed delay in ripening and senescence and reduce softening of fruits.

\section{A.3- Fruit external color measurement ( $L$ values):}

Graphs in Figure 3 clear that $\mathrm{L}$ values of tomato color were strongly affected by 1-MCP concentration and all concentrations (50, 100 and 150 $\mu \mathrm{gL}^{-1}$ ) had near magnitude and remain fixed or little declined until 21 days then slowly increased from 21 to 28 days. Color L values sharply declined within 7-14 days of storage in control fruit, then slowly increased until 28 days. In general, Maximum delay in color 1 values decline was obtained with the $150 \mu \mathrm{gL}^{-1} 1-\mathrm{MCP}$, These results agree with those results of Poyesh et al. (2017).

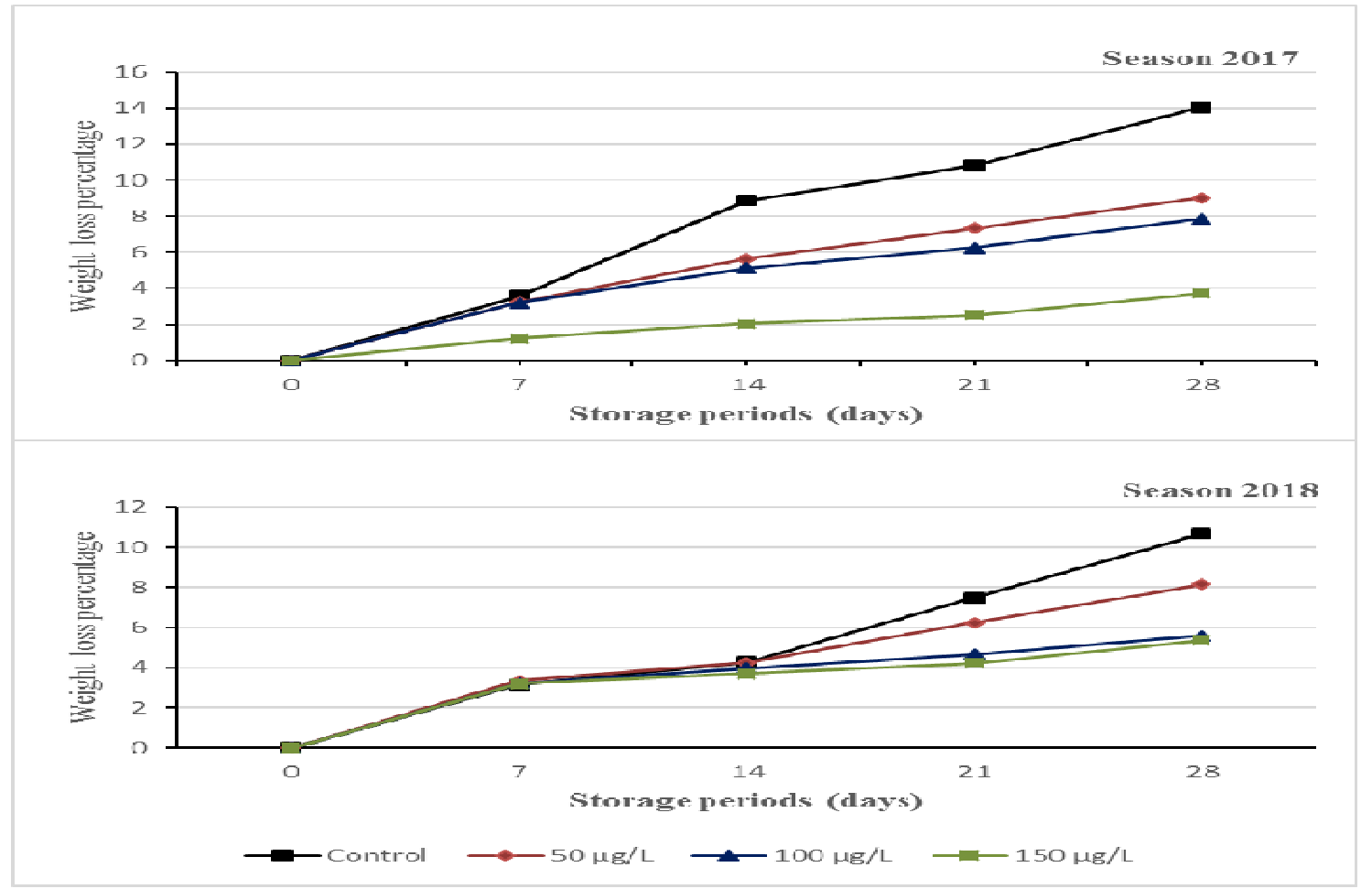

Figure 1: Tomato fruit weight loss percentage during storage periods after zero date, 7, 14, 21 and 28 days at $20{ }^{\circ} \mathrm{C}$ following treatment with 1-MCP at 0, 50, 100, and $150 \mu \mathrm{gL}^{-1}$ concentrations in season 2017 and 2018. 


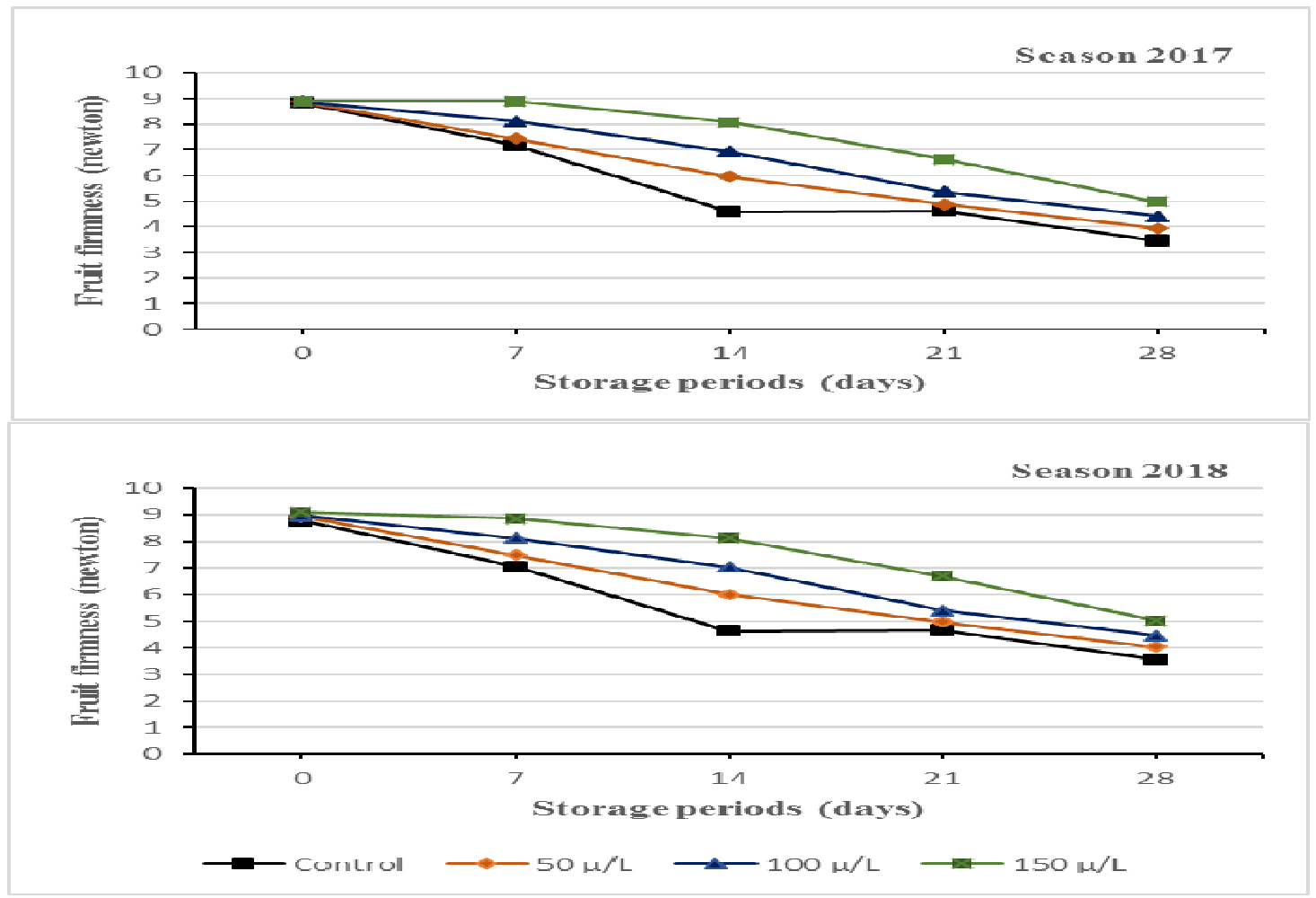

Figure 2: Tomato fruit firmness in newton during storage periods after zero date, $7,14,21$ and 28 days at $20{ }^{\circ} \mathrm{C}$ following treatment with 1-MCP at $0,50,100$, and $150 \mu \mathrm{gL}^{-1}$ concentrations in season 2017 and 2018.

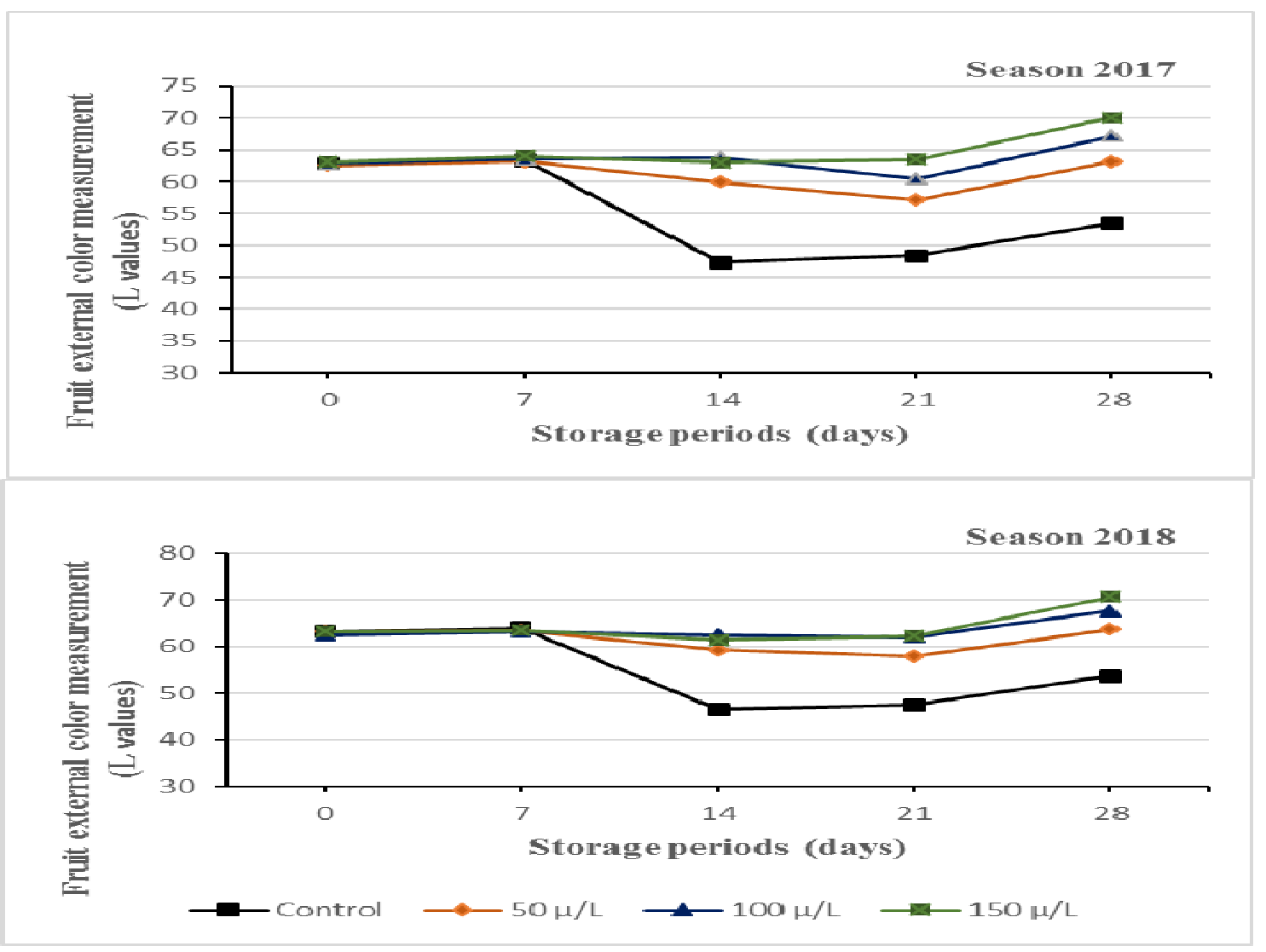

Figure 3: Tomato fruit external color ( $\mathrm{L}$ values) during storage periods after zero date, 7, 14, 21 and 28 days at 20 ${ }^{\circ} \mathrm{C}$ following treatment with $1-\mathrm{MCP}$ at $0,50,100$, and $150 \mu \mathrm{gL}^{-1}$ concentrations in season 2017 and 2018 


\section{A.4- Fruit external color measurement (C values):}

The initiated $\mathrm{C}$ values of tomato fruit color did not differ significantly from 35.99 and 36.06 in the first and second seasons, respectively for the used 1-MCP concentrations in the beginning of storage (Figure 4).

The $\mathrm{C}$ values in average of tomato fruit eternal color were noticed to be significantly increased until 28 days and were 51.28 and 52.58 at 28 days during the first and second, respectively. The $\mathrm{C}$ values in average of tomato fruit external color were 44.63 and 45.26 under control followed significantly declined under 50 $\mu \mathrm{gL}^{-1}$ of $1-\mathrm{MCP}$ concentration and were 42.57 and 43.00 then significant increased under $100{\mu \mathrm{gL}^{-1}}^{-1}$ concentration and were 43.79 and 44.30, after that significant decreased under $150 \mu \mathrm{gL}^{-1}$ concentration and were 39.15 and 40.20 in the first and second seasons, respectively, These results agree those of Cantwell et al. (2009).

A.5- Fruit external color measurement ( $H$ values): Graphs in Figure 5 clear that $\mathrm{H}$ values of tomato color were strongly affected by 1-MCP concentrations and all concentrations and control had very near magnitude and acute increased until 7 days then control sharply decreased until 14 days followed slowly increased, while 50, 100 and $150 \mu \mathrm{gL}^{-1}$ concentrations little declined until 21 days then slowly increased from 21 to
28 days. The concentration $150 \mu \mathrm{gL}^{-1}$ was the lowest treatment affected by prolonging the storage periods. These results agree those of Poyesh et al. (2017) and Sabir et al. (2012).

\section{A.6- Fruit decay}

Started decay values of the studied tomato fruit were 1 in the two seasons for all 1-MCP concentrations in the start storage period (Figure 6).

The tomato fruit decay average values in Fig. 7 did not change until 7 days, then significantly increased to value of 2.00 at 28 days in the two seasons. On the other hand, tomato fruits decay values were decreased with the increasing of 1-MCP concentrations and ranged between 1.80 and in the begging of storage to 1.00 during the two seasons, These results agree those of Guill'en et al. (2006), Castillo et al. (2006), Wang et al. (2008), Zhang et al. (2012) and Amoateng et al. (2018). Moreover, there was a significant interaction between 1MCP concentrations and storage periods, the lowest fruit decay noticed within fruits treated with $150 \mu \mathrm{gL}^{-1}$ of 1-MCP, while the highest fruit decay was noticed within untreated fruits in the two seasons. The highest decay value was 3.00 under control after 28 days, while the lowest decay value was 1.00 after 28 days as affected by $150 \mu \mathrm{gL}^{-1}$ concentration in the two seasons.

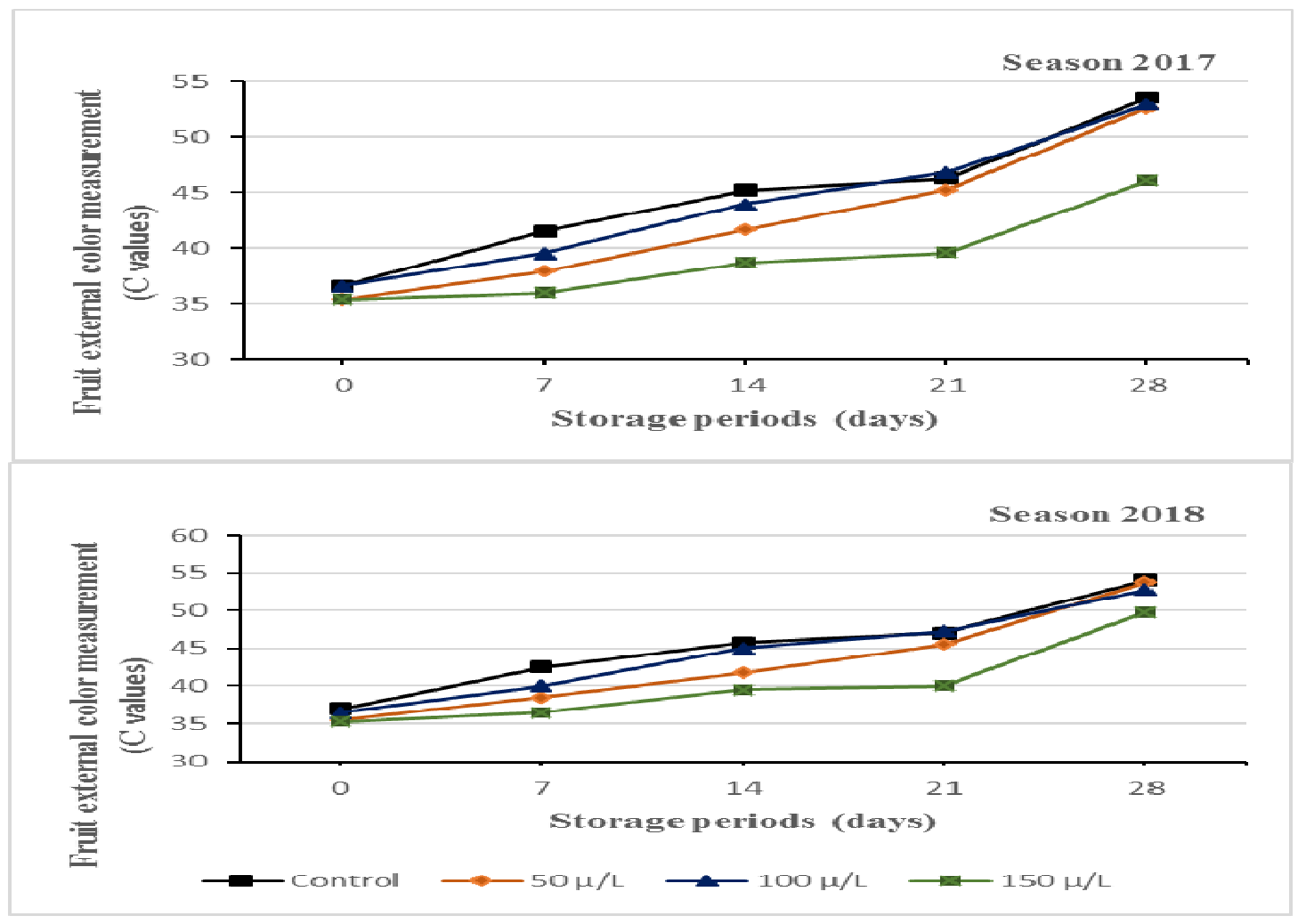

Figure 4: Tomato fruit external color (C values) during storage periods after zero date, 7, 14, 21 and 28 days at 20 ${ }^{\circ} \mathrm{C}$ following treatment with 1-MCP at $0,50,100$, and $150 \mu \mathrm{gL}^{-1}$ concentrations in season 2017 and 2018. 

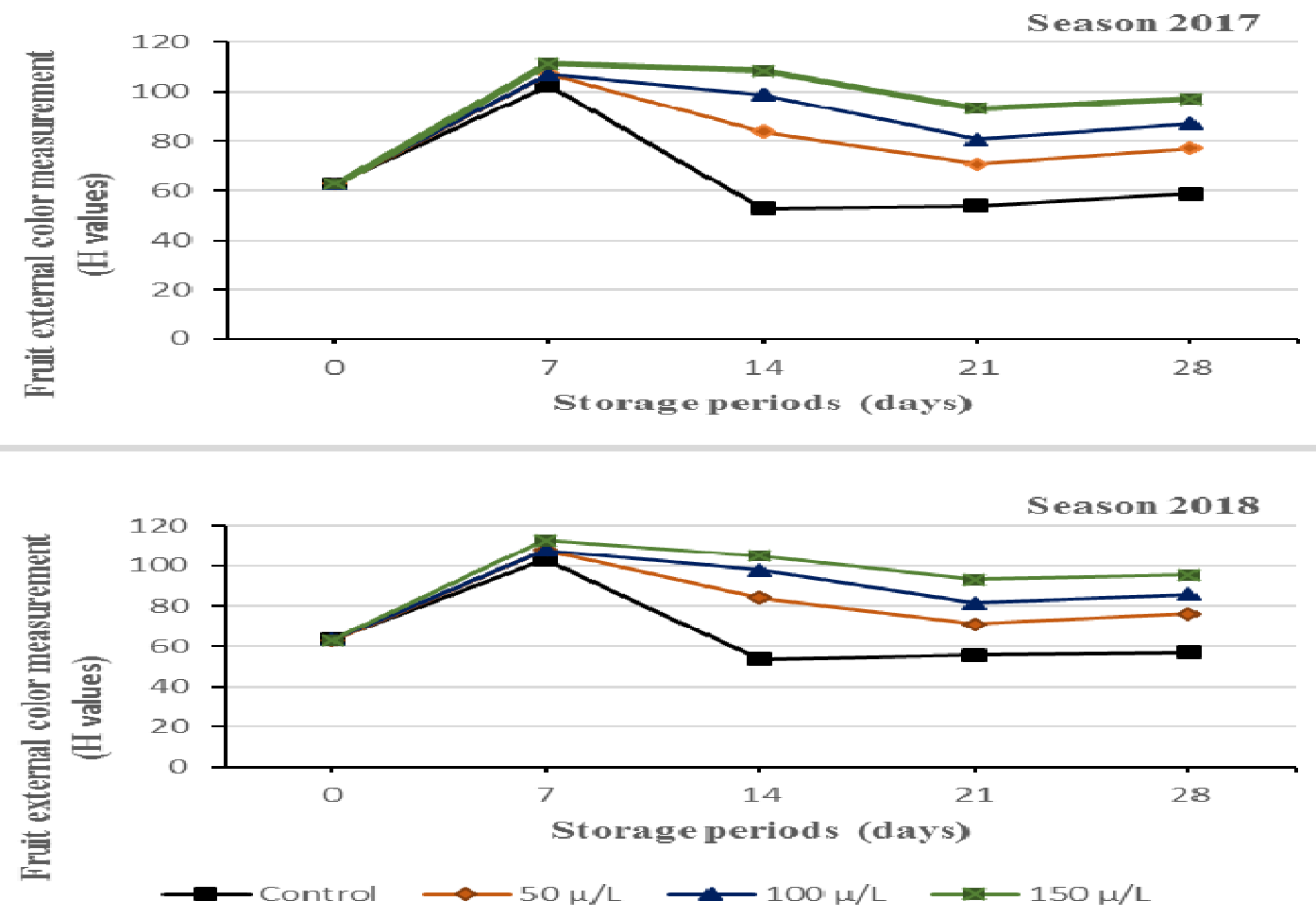

Figure 5: Tomato fruit external color (H values) during storage periods after zero date, 7, 14,21 and 28 days at $20{ }^{\circ} \mathrm{C}$ following treatment with 1-MCP at 0, 50, 100, and $150 \mu \mathrm{gL}^{-1}$ concentrations in season 2017 and 2018.
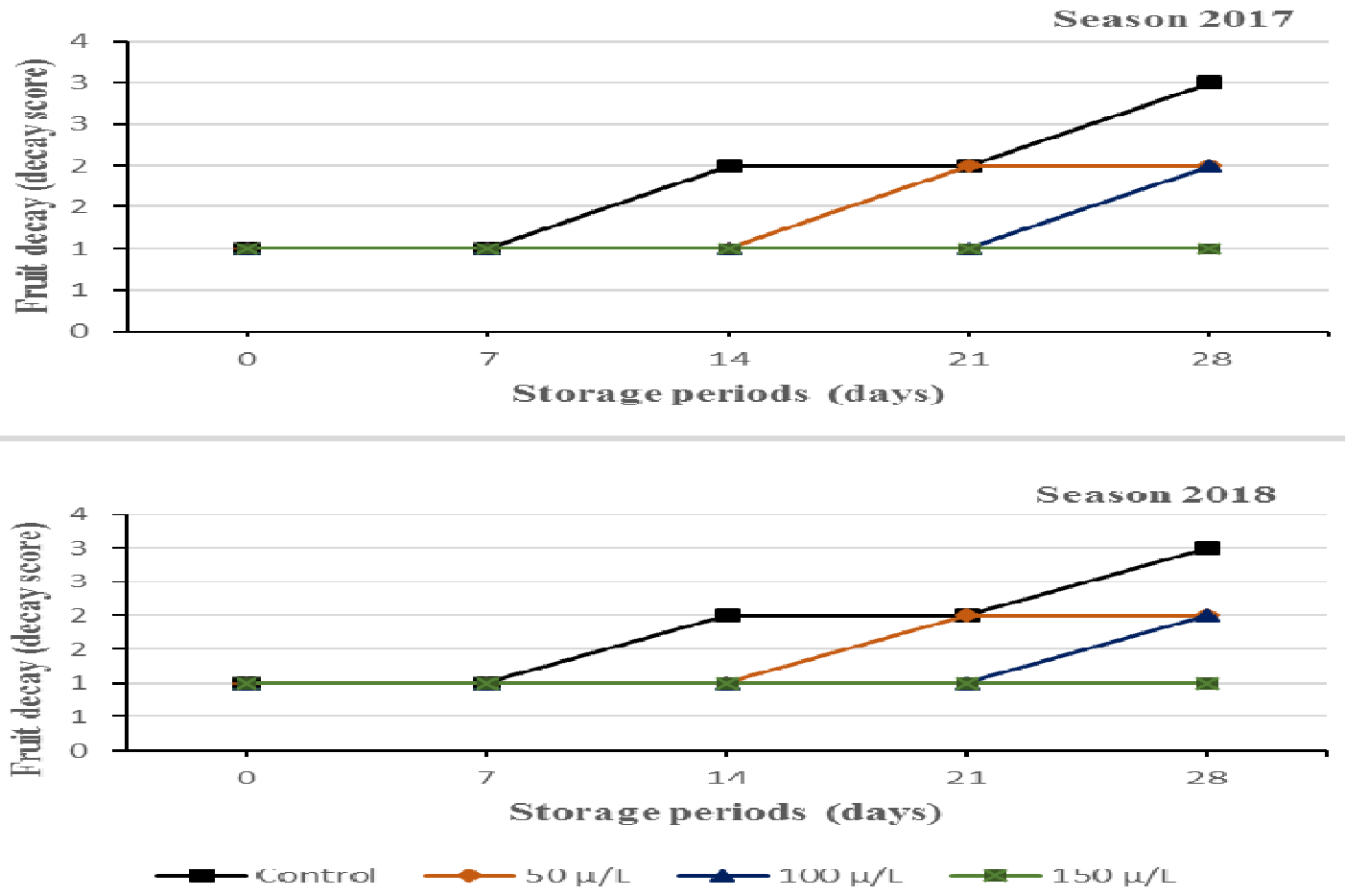

Figure 6: Tomato fruit decay during storage periods after zero date, $7,14,21$ and 28 days at $20{ }^{\circ} \mathrm{C}$ following treatment with $1-\mathrm{MCP}$ at $0,50,100$, and $150 \mu \mathrm{gL}^{-1}$ concentrations in season 2017 and 2018. 


\section{A.7- Fruit visual appearance}

The tomato fruit appearance began with score of 9 in the two seasons under all 1-MCP concentrations in the start storage period (Fig.7).

The tomato fruit visual appearance means in Fig. 9 did not change until 7 days, then significantly decreased to value of 8.00 at 28 days in the two seasons. On the other hand, tomato fruits visual appearance means were increased with the increasing of $1-\mathrm{MCP}$ concentrations and ranged between 7.40 and in the begging of storage to 9.00 during the two seasons. These results agree those of Wang et al. (2008) and Cantwell et al. (2009). As observed by Fig. 8, the fruit visual appearance was maintained at 9.00 value until 28 days by $150 \mu \mathrm{gL}^{-1}, 21$ days by $100150 \mu \mathrm{gL}^{-1}, 14$ days by $50150 \mu \mathrm{gL}^{-1}$ and 7 days by the control in the two seasons.

\section{B- Chemical characteristics}

\section{B.1- Total soluble solids T.S.S.}

The data in fig8 illustrate that total soluble solids percentage showed start value of 2.50 and $2.54 \%$ in the first and second seasons, respectively under all 1MCP concentrations in the zero date during the two seasons.

The means of total soluble solids percentages in tomato fruit were observed to be significantly increased as affected by extend of storage periods and reached 5.01 and $4.94 \%$ after 28 days in season 2017 and 2018, respectively. On the other hand, the means of these percentages were observed to be decreased as the reflect of the increasing of 1-MCP concentrations and ranged between 4.40 and $4.38 \%$ after zero date to 3.13 and $3.11 \%$ after 28 days during the first and the second seasons, respectively. These results were agreed with those results of Wills et al. (2001), Guill'en et al. (2006), Castillo et al. (2006), Wang et al. (2008), Cantwell et al. (2009), Sabir et al. (2012) and Amoateng et al. (2018).

Moreover, there was a significant interaction between 1-MCP concentrations and storage periods, the less fruit total soluble solids percentages were obtained within fruits treated with $150 \mu \mathrm{gL}^{-1}$ of $1-\mathrm{MCP}$, while the lowest fruit ones were noticed within untreated fruits in the two seasons. The highest total soluble solids percentages were 6.00 and 5.90 under control after 28 days, while the lowest percentages were 4.03 and 4.10 after 28 days as affected by $150 \mu \mathrm{gL}^{-1}$ concentration in the first and second seasons, respectively.

B.2- Ascorbic acid content

The initial tomato content of ascorbic acid for the breaker stage was around $5.55 \mathrm{mg} \mathrm{ml}^{-1}$ in season 2017 and $5.47 \mathrm{mg} \mathrm{ml}^{-1}$ in season 2018 without significant differences among the different concentrations of 1-MCP (Figure 9).

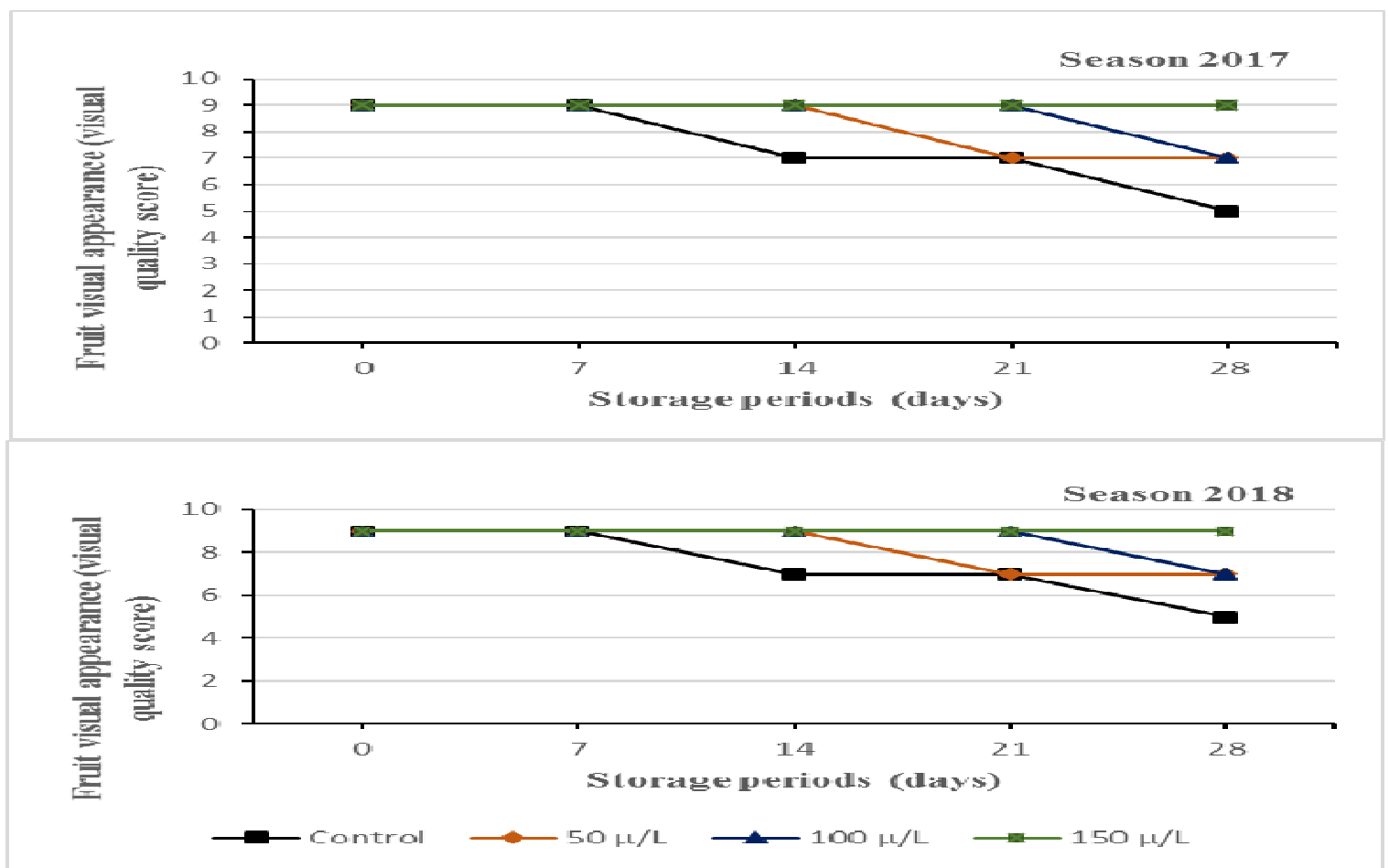

Figure 7: Tomato fruit visual appearance during storage periods after zero date, 7, 14, 21 and 28 days at $20{ }^{\circ} \mathrm{C}$ following treatment with $1-\mathrm{MCP}$ at $0,50,100$, and $150 \mu \mathrm{gL}^{-1}$ concentrations in season 2017 and 2018.

The average of ascorbic acid contents in tomato fruit (Figure 9) were significantly enhanced as a result of increased length of storage times and gave 10.88 and $10.95 \mathrm{mg} \mathrm{ml}^{-1}$ after 28 days in the two seasons. On the contrary, the means of these contents were observed to be declined as a result of the increasing of 1-MCP concentrations and ranged between 10.78 and $10.70 \mathrm{mg} \mathrm{ml}^{-1}$ after zero date to 6.81 and $6.77 \mathrm{mg} \mathrm{ml}^{-1}$ after 28 days in 2017 and 2018 seasons, respectively, These results agree those of Wang et al. (2008), Marita Cantwell et al. (2009), Sabir et al. (2012) and Amoateng et al. (2018). 
The general trend in Fig.9 was that ascorbic acid contents were in steadily increment with the increasing length of storage times under all studied treatments. The control treatments showed a cute increasing between zero date to 14 days then little increasing after that in the two seasons. The concentrations of 100 and $150 \mu \mathrm{gL}^{-1}$ were between the control and $150 \mu \mathrm{gL}^{-1}$ had near magnitudes and the concentrations 50 and $100 \mu \mathrm{gL}^{-1}$ been between the control and $150 \mu \mathrm{gL}^{-1}$.
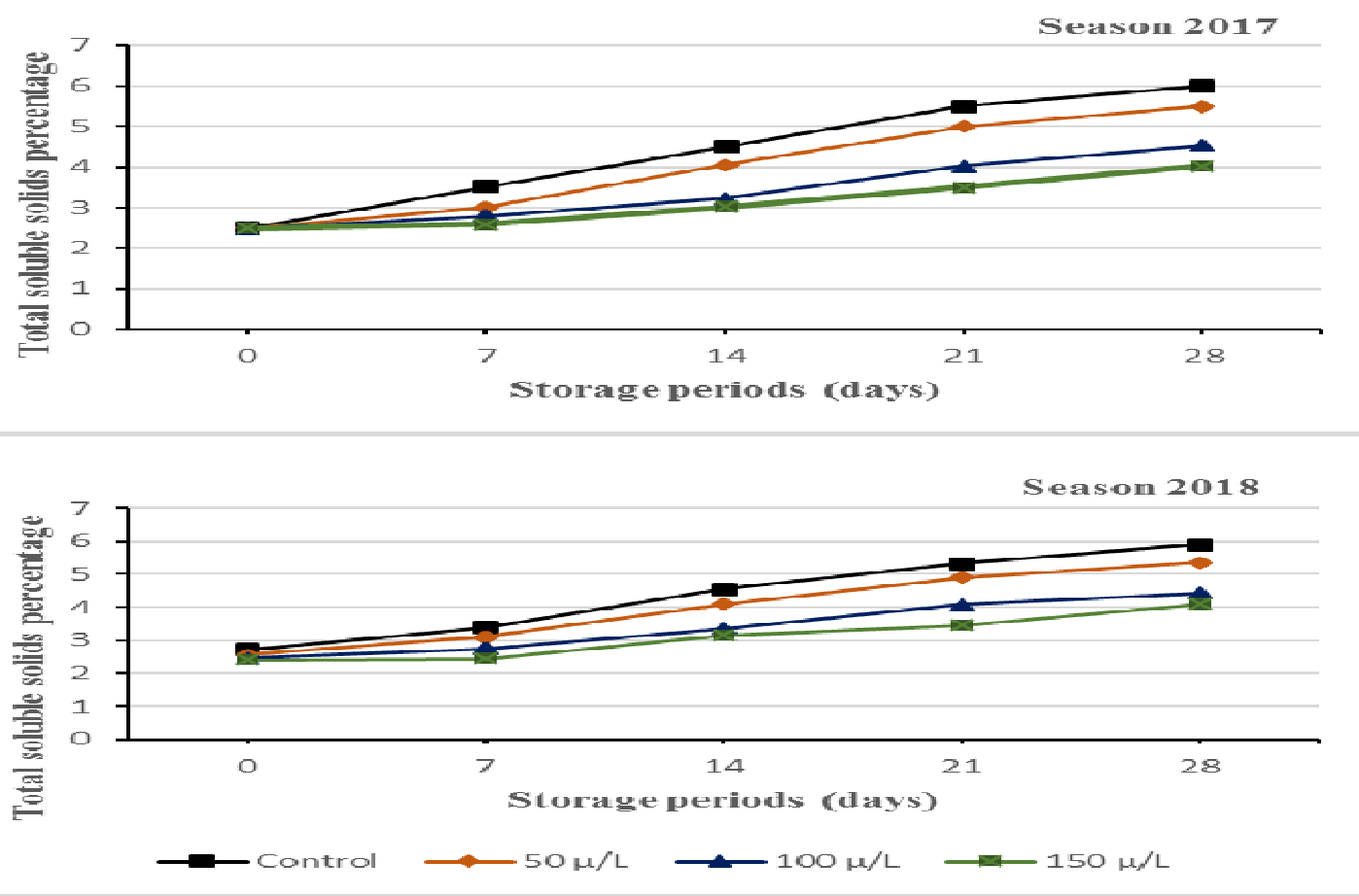

Figure 8: Tomato fruit contents of total soluble solids percentage during storage periods after zero date, 7, 14, 21 and 28 days at $20{ }^{\circ} \mathrm{C}$ following treatment with $1-\mathrm{MCP}$ at $0,50,100$, and $150 \mu \mathrm{gL}^{-1}$ concentrations in season 2017 and 2018.
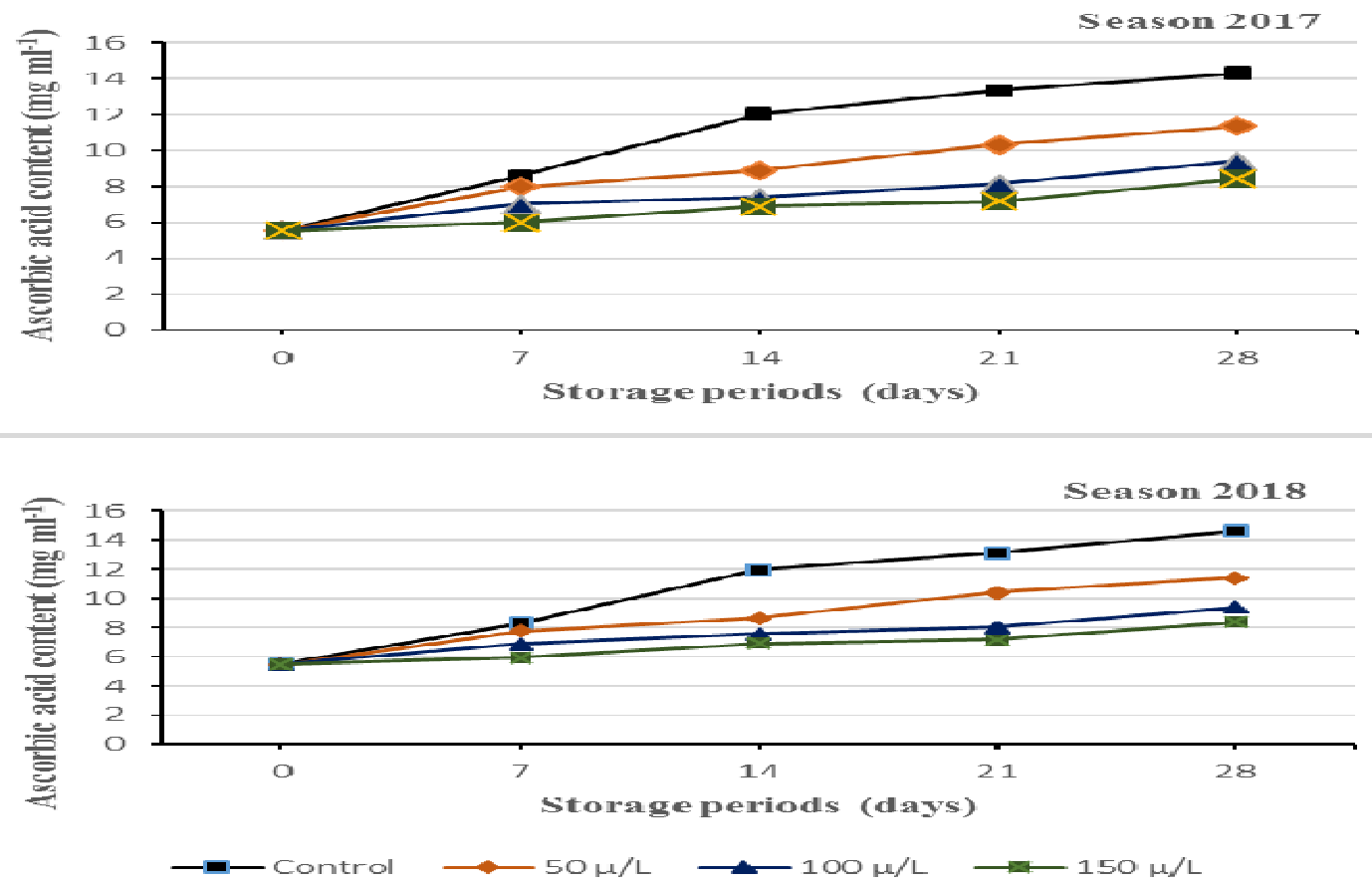

Figure 9: Tomato fruit contents of ascorbic acid $\left(\mathrm{mg} \mathrm{ml}^{-1}\right)$ during storage periods after zero date, 7, 14, 21 and 28 days at $20{ }^{\circ} \mathrm{C}$ following treatment with $1-\mathrm{MCP}$ at $0,50,100$, and $150 \mu \mathrm{gL}^{-1}$ concentrations in season 2017 and 2018 


\section{B.3- Titratable acidity}

The tomato content of titratable acidity for the start period of storage was around 0.690 and $0.691 \mathrm{~g}$ $100 \mathrm{ml}^{-1}$ in the first and second seasons, respectively without significant differences among the different concentrations of 1-MCP (Figure 10).

The means of the titratable acidity in tomato fruit were significantly decreased corresponding to the continues storage days and reached to 0.594 and $0.596 \mathrm{~g}$ $100 \mathrm{ml}^{-1}$ after 28 days in the first and second seasons, respectively. On the other hand, the means of tomato fruits contents of titratable acidity were observed to be significantly increased with the increasing of $1-\mathrm{MCP}$ concentrations and ranged between 0.613 and $0.614 \mathrm{~g}$

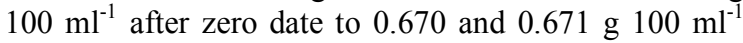
after 28 days during the first and the second seasons, respectively, These results were agreement with those obtained by Kaynas and Sumeli, (1995) who found that titratable acidity reduced during storage at $4{ }^{\circ} \mathrm{C}$. The reduction in fruit acidity during storage might be attributed to the rapid rate of oxidation of pyruvic acid and other acids to carbon dioxide (Wills et al., 1981).

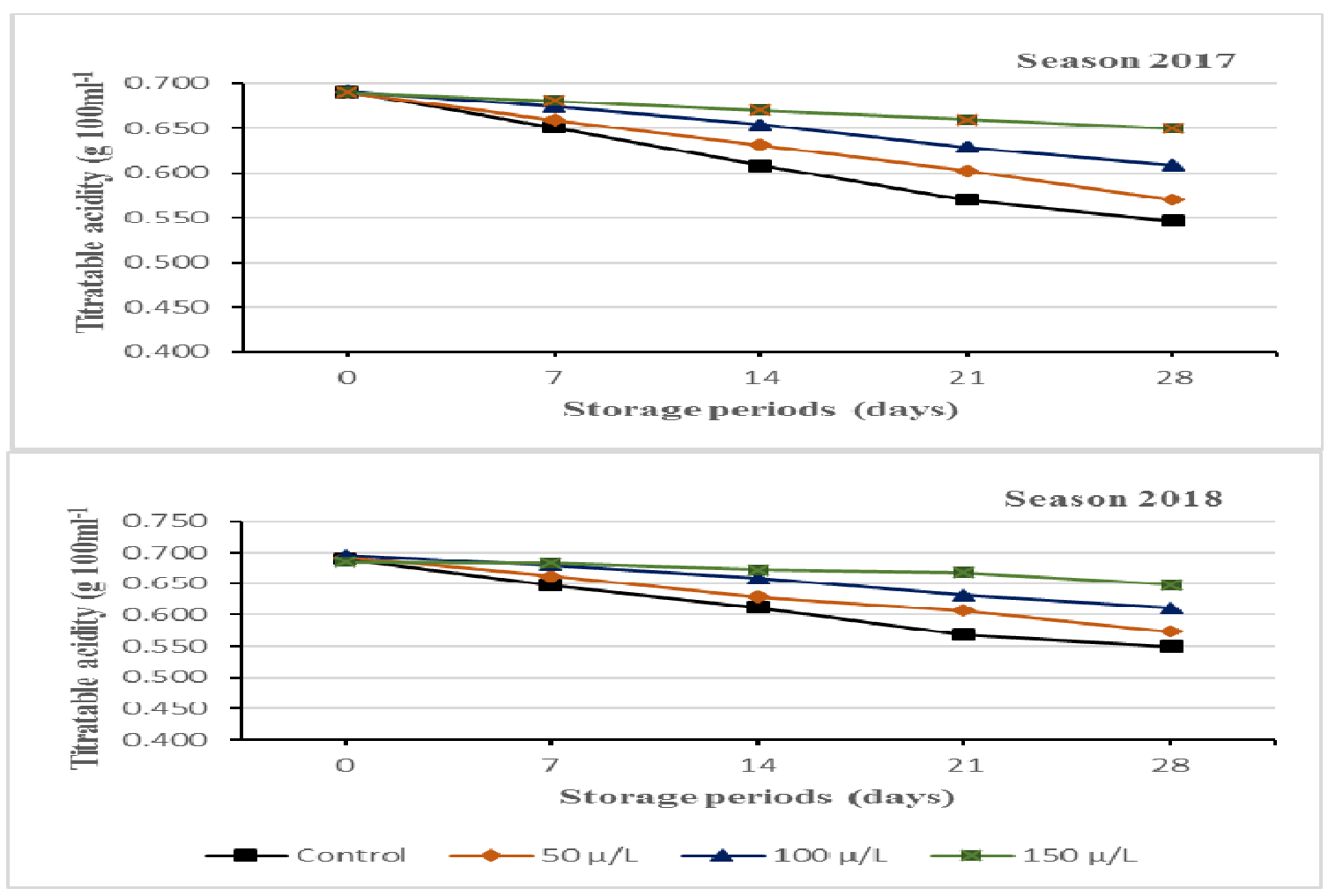

Figure 10: Tomato fruit contents of titratable acidity $\left(\mathrm{g} 100 \mathrm{ml}^{-1}\right)$ during storage periods after zero date, 7, 14, 21 and 28 days at $20{ }^{\circ} \mathrm{C}$ following treatment with $1-\mathrm{MCP}$ at $0,50,100$, and $150 \mu \mathrm{gL}^{-1}$ concentrations in season 2017 and 2018.

\section{CONCLUSION}

From the previous results it could be concluded that the Suppression of ripening was concentration dependent, with maximum inhibition in response for 10 min immersion occurring at concentrations of 100and

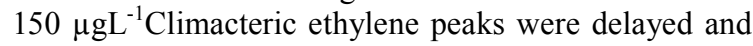
respiration was strongly suppressed in fruit treated with aqueous treatment of 1-MCP at 50,100, and $150 \mu \mathrm{gL}^{-1}$, respectively, compared with control fruit.

\section{REFERENCES}

A.O.A.C. (2000). Association of Official Analytical Chemists, Washington DC. USA.

Amoateng, M. E., P. Kumah and I. Yaala (2018). Effect of postharvest application of different concentrations of 1-methylcylclopropene on Quality and Shelf-life of Two Tomato (Solanum lycopersicum) Cultivars. Agric. and Ecology Res. Int. J., 14(1): 1-11.

Baider, A., and Y. Cohen (2003). Synergistic interaction between BABA and mancozeb in controlling Phytophthora infestans in potato and tomato and Pseudoperonospora cubensis in cucumber. Phytoparasitica J., 31(4), 399-409.

Blankenship, S.M. and J.M. Dole. (2003). 1Methylcyclopropene: a review. Postharvest Biol. Technol. J., 28: 1-25.

Castillo, S., Guillén, F., G. Bailén, D. MartínezRomero, P.J. Zapata, M. Serano and D. Valero (2006). Efficacy of 1-MCP treatment in tomato fruit. 1. Duration and concentration of 1-MCP treatment to gain an effective delay of postharvest ripening. Postharvest Biol. Technol. J. 10:07-014. 
Celso, L.M., A.M. Waldir and L.C.S. Washington (2001). Scheduling tomato fruit ripening with 1methylcyclopropene. Proc. Fla. State Hort. Soc. 114:145-148.

El-Sheikh, T.M. (1998). Physiological studies on yield, quality and storability of tomato fruits. Annals of Agric. Sc., Moshtohor J., 36(1): 513-525.

FAO STAT (2014) Food and Agriculture Organization of the United Nations.

Grandillo S., H.M. Ku, and S.D. Tanksley ( 1999). Identifying the loci responsible for natural variation in fruit size and shape in tomato. Theory Appl. Genet., 978-987

Guillén, F., S. Castillo, G. Bailén, D. Martínez-Romero, P.J. Zapata, M. Serano and D. Valero (2006). Efficacy of 1-MCP treatment in tomato fruit. 1. Duration and concentration of 1-MCP treatment to gain an effective delay of postharvest ripening. Postharvest Biol. Technol. J.,7:10101016.

Kader, A.A. (Ed). (1992). Postharvest technology of horticultural crops ( $2^{\text {nd }}$ Edition). UC Publication 3311. University of California, Division of Agriculture and Natural Resources, Oakland, California 94608.

Kaynas, K. and N. Sumeli (1995). Characteristics at various ripening stage of tomato fruits stored at different temperatures. Tukish. J. Agriculture and Forestry. 19(4): 277-285.

Marita Cantwell, M. (2009). Optimum Procedures for Ripening Tomatoes. In: Fruit Ripening and Ethylene Management, J.T. Thompson and C. Crisosto (eds.), UC, Postharvest Horticulture Series 9:106-116.

Meng, X. H.; J. Han; Q. Wang and S. P. Tian (2008). Changes in physiology and quality of peach fruits treated by methyl jasmonate under low temperature stress. Food Chem., 114: 1028-1035.

Poyesh, D.S., N. Terada, A. Sanada, A. Gemma and K. Koshio (2017). Effect of 1-MCP on ethylene regulation and quality of tomato cv. Red Ore. Int. J. Food and Agric. Res. 25(3): 1001-1006.

Prigojin, I., E. Fallik,Y. Qat, I. Ajalin, H. Allam, M. Ezzat, M. Almasri and M. Bader (2005). Middle East regional agricultural program - survey on postharvest losses of tomato fruit (Lycopersicon esculentum) and table grapes (Vitis vinifera). Acta Hort. 682:1049-1056.

Sabir, R. I., N. Akhtar, F. A. S. Bukhari, J. Nasir and W. Ahmed (2012). Impact of training on productivity of employees: a case study of electricity supply company in pakistan. Int. Rev. Management and Business Res., 3(2), 595

Unnikrishnan, V. and B. S. Nath (2002). Hazardous chemicals in foods. Indian J. of Dairy Biosciences, 11: 155-158.

Watkins, C.B. (2002). Ethylene synthesis and mode of action, consequences and control. In: knee, M. (Ed.), Fruit quality and its biological basis. Sheffield Academic Press, 180-224.

Wills, R.H.H., T.H. Lee, D. Gerham, W.B. Mc Glsson and E.G. Hall (1981). Postharvest and introduction to physiology and handling of fruits and vegetables. The AVF Publishing Com. Fnc. Westport. Conn. Pp 35.

Zhang, Z., T. Shiping, Z. Zhu, X. Yong and Q. Guozheng (2012). Effects of 1methylcyclopropene (1-MCP) on ripening and resistance of jujube (Zizyphus jujuba cv. Huping) fruit against postharvest disease. Food Sci. and Technol., 45: 13-19.

\footnotetext{
تأثير معاملة 1-MCP على حفظ جودة ثمار الطماطم عند درجة الحرارة المحيطة

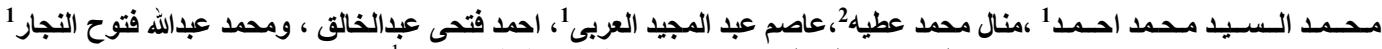

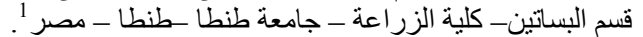

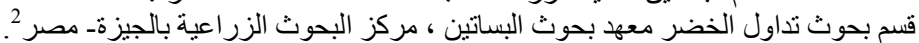

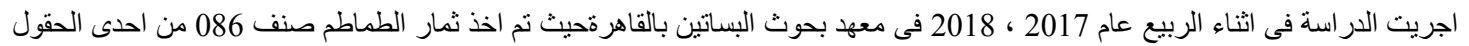

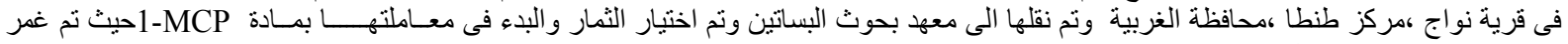

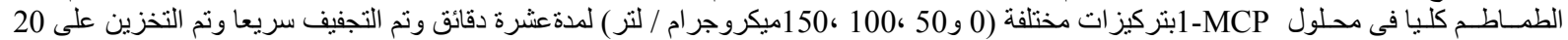

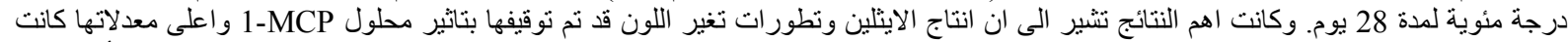

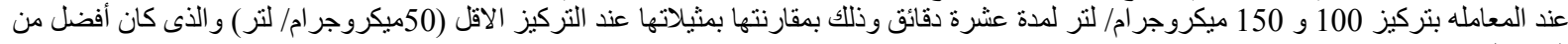

